\title{
Aluminum accumulation in two Pfaffia glomerata genotypes and its growth effects
}

\author{
Acumulação de alumínio em dois genótipos de Pfaffia glomerata e seus efeitos no crescimento
}

\begin{abstract}
Joseila Maldaner ${ }^{\mathrm{I}}$ Fernando Teixeira Nicoloso ${ }^{\text {II }}$ II $^{*}$ Luciane Almeri Tabaldi ${ }^{\text {II }}$ Denise Cargnelutti $^{\mathrm{V}}$ Etiane Caldeira Skrebsky ${ }^{\mathrm{VI}}$ Renata Rauber ${ }^{\mathrm{II}}$ Jamile Fabbrin Gonçalves $^{\mathrm{IV}}$ Liana Verônica Rossato $^{\mathrm{III}}$
\end{abstract}

\begin{abstract}
Aluminum (Al) toxicity is a limiting factor for crop production in acid soils, which cover approximately $60 \%$ of the Brazilian territory. This study aimed to evaluate the effects of Al on growth and tissue Al concentration of two Pfaffia glomerata accessions (BRA and JB/UFSM). Plantlets were grown in a hydroponic system with five Al concentrations (0, 50, 100, 150 and $200 \mathrm{mg} \mathrm{L}^{-1}$ ) for 7 days. Most of the evaluated parameters presented significant interaction between both $\boldsymbol{P}$. glomerata accessions and Al levels in nutrient solution and, in general, Al treatments negatively affected plant growth, especially roots. Moreover, BRA accession showed higher Al accumulation in its tissues than $J B / U F S M$ and, consequently in BRA accession the growth was impaired substantially. Furthermore, the results suggest that between P. glomerata accessions studied, BRA is less appropriated for medicinal uses when grown in soils with high Al levels, due to the higher accumulation of tissue Al content.
\end{abstract}

Key words: Brazilian Ginseng, acid soils, Al toxicity.

\section{RESUMO}

A toxidez do alumínio (Al) é um fator limitante da produção agrícola em solos ácidos, os quais cobrem cerca de $60 \%$ do território Brasileiro. Oobjetivo deste estudo foi avaliar os efeitos do Al no crescimento e na concentração de Al nos tecidos de dois acessos de Pfaffia glomerata (BRA e JB/UFSM). As plantas foram cultivadas em sistema hidropônico, contendo cinco concentrações de Al (0, 50, 100, 150 e 200mg $\left.L^{-1}\right)$ por 7 dias. Para a maioria dos parâmetros avaliados, houve interação significativa entre os dois acessos de P. glomerata e as concentrações de Al, sendo que, de modo geral, os tratamentos com Al afetaram negativamente o crescimento das plantas, especialmente as raizes. Além disso, o acesso BRA acumulou mais Al nos tecidos que o acesso JB/ UFSM e, consequentemente, os parâmetros de crescimento foram afetados mais significativamente naquele acesso. Portanto, nossos resultados sugerem que, entre os acessos de P. glomerata estudados, BRA é menos indicado para usos medicinais quando cultivado em solos com altos níveis de Al, por acumular mais Al em seus tecidos.

Palavras-chave: Ginseng Brasileiro, solos ácidos, toxicidade de Al.

\section{INTRODUCTION}

Aluminum (Al) is the most abundant metal in the Earth's crust and plants grown in soil environments in which roots that are potentially exposed to high $\mathrm{Al}$ concentrations may have their growth hampered (HORST et al., 2010). Since a large part of the world's total land area consists of acid soil, much attention has been paid to $\mathrm{Al}$ toxicity and plant resistance mechanisms (KOCHIAN et al., 2004). Aluminum toxicity inhibits both cell division and root tip elongation (FORTUNATO \& NICOLOSO, 2004; HORST et al., 2010), decreasing the root volume, number of lateral roots and increasing the permeability of plasma membrane (YU et al., 2011), thus hindering plants' water supply and nutrient uptake mechanisms (VITORELLO et al., 2005), however its effects may be plant species dependent.

IFundação Estadual de Pesquisa Agropecuária, Centro de Pesquisa Iwar Beckman, Hulha Negra, RS, Brasil.

IIDepartamento de Biologia, Universidade Federal de Santa Maria (UFSM), 97105-900, Santa Maria, RS, Brasil. E-mail: ftnicoloso@yahoo.com.*Corresponding author.

IIIPrograma de Pós-graduação em Agronomia, UFSM, Santa Maria, RS, Brasil.

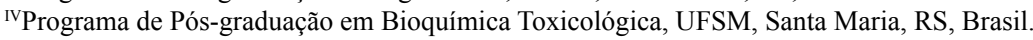

vUniversidade Federal da Fronteira Sul, Erechim, RS, Brasil.

${ }^{\mathrm{VI}}$ Universidade Federal do Pampa, Dom Pedrito, RS, Brasil. 
Inorganic monomeric octahedral hexahydrate, $\mathrm{Al}\left(\mathrm{H}_{2} \mathrm{O}\right)_{6}{ }^{3+}$, or $\mathrm{Al}^{3+}$, is the principal rhizotoxic form in acid soils (HORST et al., 2010). Common responses of $\mathrm{Al}^{3+}$ toxicity in shoots are related to nutritional and water deficiencies, which results in cellular and ultrastructural changes (PEREIRA et al., 2006). Moreover, lower stomatal conductance, decreased photosynthetic activity, chlorosis and necrosis of leaves, total decrease in leaf number and size, and decrease in shoot biomass have been reported (HORST et al., 2010). However, among genotypes or cultivars within the same species there is genetic variability for tolerance to $\mathrm{Al}^{3+}$ toxicity (TABALDI et al., 2009; SINGH et al., 2011), which has allowed the selection of tolerant and productive genotypes, for the utilization of acid soils in biomass production.

Pfaffia glomerata (Spreng.) Pedersen, known as Brazilian Ginseng, is a medicinal plant belonging to the Amaranthaceae family. Its medicinal activity is attributed to a number of compounds identified in several Pfaffia species, such as glomeric acid, a triterpenoid, and pfameric acid, a nortriterpenoid, as well as ecdysterone, rubrosterone, oleanolic acid and beta-glucopyranosyl oleanolate, which have been isolated from its roots (NISHIMOTO et al., 1987). As roots of $\boldsymbol{P}$. glomerata might contain $\mathrm{Al}$ and this metal is involved in the formation of neurofibrillary tangles, amyloid plaques, granulovacuolar degeneration, and other pathological changes of Alzheimer's disease (WALTON, 2012), it is important to determine genotypic differences of $\boldsymbol{P}$. glomerata regarding tissue $\mathrm{Al}$ accumulation and characterize the effects of increasing Al levels on the growth of different accessions.

\section{MATERIAL AND METHODS}

Pfaffia glomerata (Spreng.) Pedersen plantlets, accessions BRA and JB/UFSM, were obtained from in vitro culture in MS medium (MURASHIGE \& SKOOG, 1962) supplemented with $0.6 \%$ agar, $30 \mathrm{~g} \mathrm{~L}^{-1}$ of sucrose and $0.1 \mathrm{~g} \mathrm{~L}^{-1}$ of myo-inositol, under climatizated room conditions according to NICOLOSO et al. (2001). Twenty fiveday-old plantlets were transferred to plastic boxes (10 L) covered by polystyrene plates with holes that were used as a physical support for the plants; roots were submerged in aerated full nutrient solution of low ionic strength with the following composition $(\mathrm{mg}$ $\mathrm{L}^{-1}$ ): $85.31 \mathrm{~N} ; 7.54 \mathrm{P} ; 11.54 \mathrm{~S} ; 97.64 \mathrm{Ca} ; 23.68 \mathrm{Mg}$; $104.75 \mathrm{~K} ; 176.76 \mathrm{Cl} ; 0.27 \mathrm{~B} ; 0.05 \mathrm{Mo} ; 0.01 \mathrm{Ni} ; 0.13$ $\mathrm{Zn} ; 0.03 \mathrm{Cu} ; 0.11 \mathrm{Mn}$ and $2.68 \mathrm{Fe}$.
After two weeks of plantlets acclimatization, $\mathrm{Al}\left(\right.$ as $\left.\mathrm{AlCl}_{3} \cdot 6 \mathrm{H}_{2} \mathrm{O}\right)$ was added to the nutrient solution in five concentrations $(0,50,100$, 150 and $200 \mathrm{mg} \mathrm{L}^{-1}$ ). The experiment was laid out in completely randomized design and three replicates were made for each treatment. The $\mathrm{pH}$ solution was adjusted daily to $4.5 \pm 0.2$ by titration with $\mathrm{HCl}$ or $\mathrm{NaOH}$ solution of $0.1 \mathrm{M}$. The nutrient solution was continuously aerated. At harvest, after seven days of Al exposure, plants were divided into roots and shoots. Roots were rinsed twice with distilled water. Fresh and dry biomass parameters were determined by measurements on an analytical weighing device. To obtain dry weight, roots and shoots were dried at $65^{\circ} \mathrm{C}$ until reaching a constant weight.

Dried and ground plant tissues $(0.2 \mathrm{~g})$ were digested by $\mathrm{H}_{2} \mathrm{O}_{2} \mathrm{e}_{2} \mathrm{SO}_{4}$, in an open system utilizing a block digester. Aluminum concentration was determined by Inductively Coupled Plasma Optical Emission Spectrometry (ICP OES) Perkin Elmer Optima $4300 \mathrm{DV}$ (Whaltam, USA) equipped with a cyclonic spray chamber and a concentric nebulizer. A standard calibration curve was prepared for the $0-200 \mathrm{mg} \mathrm{L}^{-1} \mathrm{Al}$ concentration range.

Length of roots was measured according to TENNANT (1975), while the length of shoot (larger and smaller shoot) was measured with a ruler. The numbers of leaves, of sprouts and nodal segments were visually counted.

The experimental data were submitted to analysis of variance. The individual response of plants growth parameters was evaluated by polynomial regressions at $5 \%$ probability error. The mean differences were compared by Tukey's multiple range test $(\mathrm{P}<0.05)$ for qualitative parameter when interaction were not significant.

\section{RESULTS AND DISCUSSION}

There was a significant interaction between P. glomerata accessions and aluminum (Al) supply for most of the evaluated parameters. Al concentration in both roots and shoots of BRA and JB/UFSM accessions increased with increasing Al levels (Figure 1a and $1 \mathrm{~b}$ ), showing a quadratic response to Al supply, except in root of BRA accession that showed a linear response to Al supply. In this study, calculations with 'Visual MINTEQ' showed that $83-90 \%$ of the nominal $\mathrm{Al}$ concentration (based on initial ion concentration) was in the monomeric form $\mathrm{Al}^{3+}$ (data not shown). Moreover, most of Al taken up by plants was accumulated in roots, where it was more than 10fold higher than in shoot (Figure 1a and 1b), which 
a

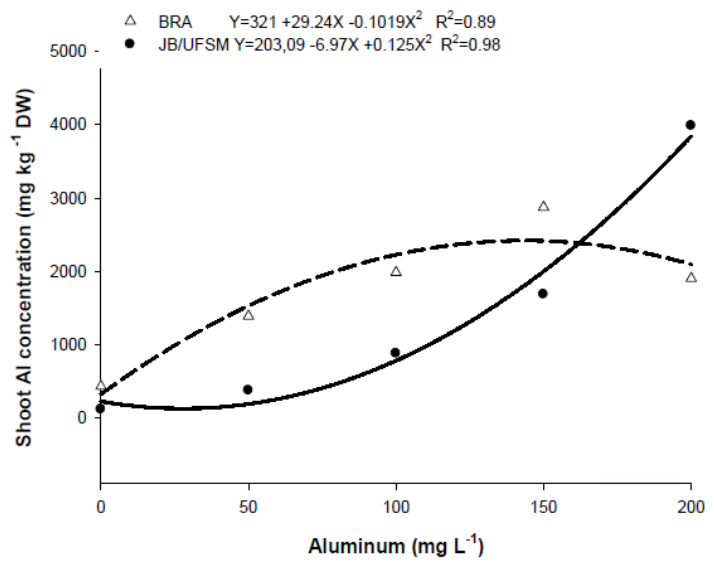

b

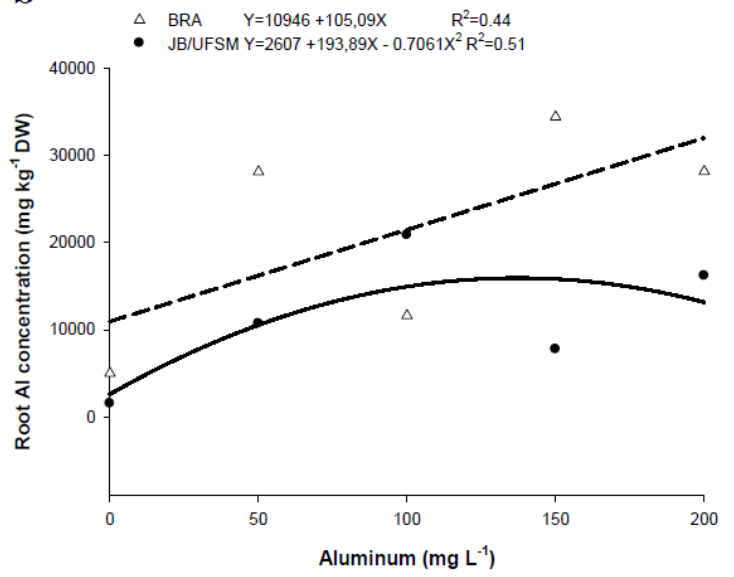

Figure 1 - Aluminum concentration in shoots (a) and root (b) of Pfaffia glomerata BRA and JB accessions exposed to Al concentrations.

suggests low Al translocation. This low translocation to shoot may be due to $\mathrm{Al}$ retention in roots by interactions with ationic ions in the cell wall. It has been extensively hypothesized that metals interact with the cell wall through interactions with pectin (KOPITTKE et al., 2008). TABALDI et al. (2009) also observed that Al accumulated more in roots than in shoot of two potato clones (on average of 3.9- and 3.6-fold greater in roots than in shoot, respectively in Macaca and SMIC148-A clones). Moreover, many reports have shown that the absorbed Al was accumulated preferentially in roots apices (KOCHIAN et al., 2004; HORST et al., 2010; YU et al., 2011).

Several studies have pointed to the ability of many plants to accumulate metals when grown in metal polluted soils or irrigated with polluted water. Some hyperaccumulator plants, which may serve as a good tool for phytoremediation, are characterized by a shootto-root metal concentration ratio (i-e. the translocation factor) of more than 1, whereas non-hyperaccumulator plants usually have higher metal concentrations in the roots than in the shoots (AL-QAHTANI, 2012). Based on previous studies (SKREBSKY at al., 2008; CALGAROTO et al., 2011; GUPTA et al., 2011), P. glomerata plants may accumulate considerable amounts of metals such as mercury, lead and cadmium in the roots without extensive damage to the plants. In this study, BRA accession had significantly higher (two fold) root Al concentration than JB/UFSM accession (Figure 1b). Thus, as $\boldsymbol{P}$. glomerata roots are the main organ used in popular medicine and our results showed that JB/UFSM seems to be a lower accumulator than the BRA accession, the choice of one accession over another may be important for medicinal purposes. There are many mechanisms involved in Al exclusion or Al tolerance (BRUNNER \& SPERISEN, 2013) and some of them may actively differentiate between P. glomerata accessions. Genotypic differences in Al tolerance have been well described for many crops including buckwheat (YANG et al., 2005), potato (TABALDI et al., 2009), and oat (CASTILHOS et al., 2011).

In general, the data in the present study showed that roots exhibited higher growth reduction than many of shoots parameter evaluated under Al stress (Figure 2). Root length decreased significantly by Al supply showing a quadratic response in both JB/UFSM and BRA accessions (Figure 2a). Although some studies reported that root growth could be stimulated initially by $\mathrm{Al}$ in the culture medium, this initial stimulus was typically followed by severe inhibition of root growth and irreversible destruction of the apical meristem (FOY, 1984). There was good agreement with our findings, since inhibition of root tip growth or root elongation, phenomena well described as root pruning, is the most common symptom of Al toxicity (VITORELLO 


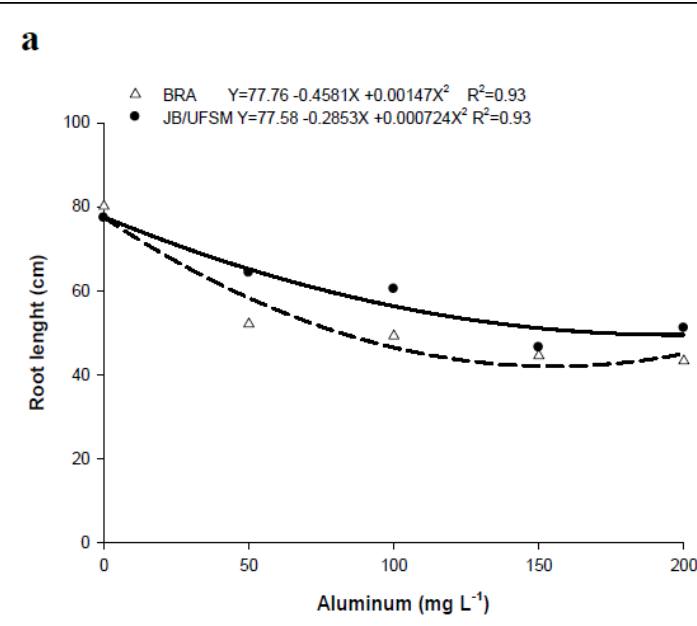

b

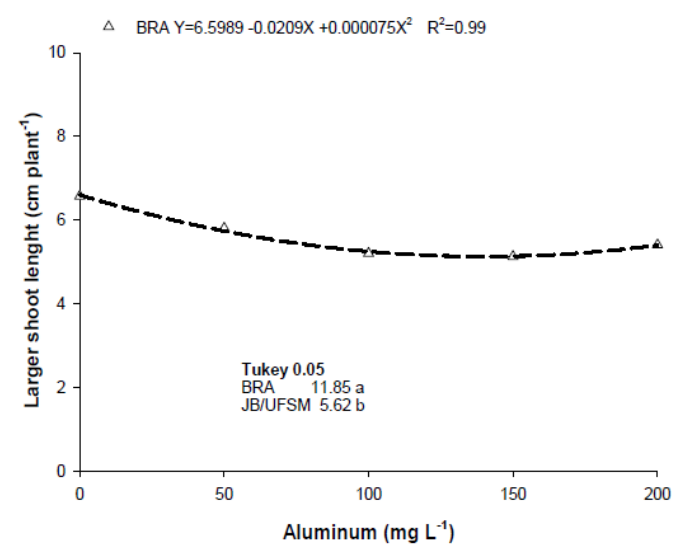

c

d

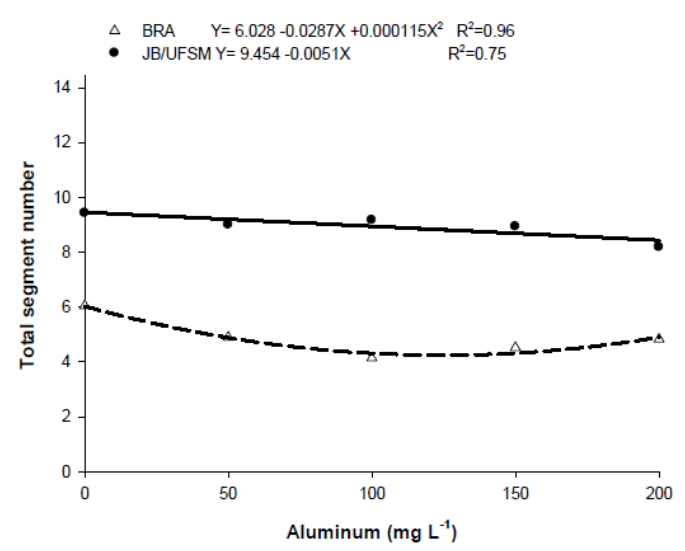

e

f

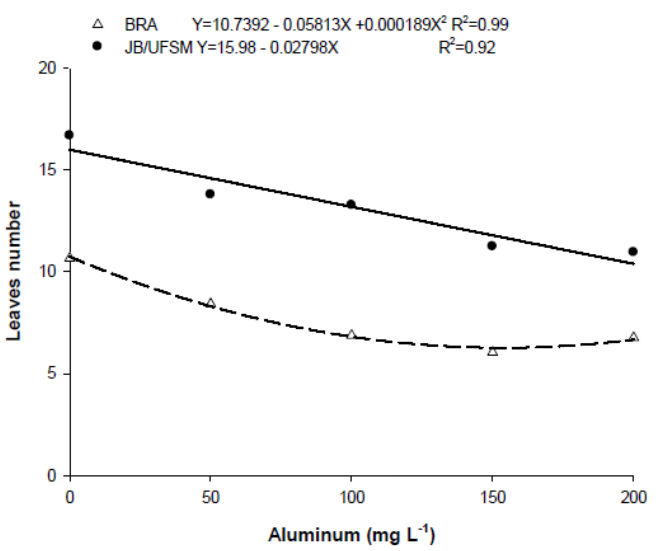

Figure 2 - Effect of increasing concentration of Al on the root length (a) larger shoot length (b), smaller shoot length (c), total segment number (d), sprouts number (e) and leaves number (f) of two accessions (BRA and JB/UFSM) of Pfaffia glomerata. Tukey test was applied when regression was not significant. 
et al., 2005; MIYASAKA et al., 2007). According to KOCHIAN (2004), the inhibition of root growth caused by $\mathrm{Al}$ is the result of reduction in cell division, pointing to a correlation between inhibition of root elongation and cessation of mitotic figures in the root meristem. Furthermore, some morphologic alterations that cause roots to be inefficient in absorption and translocation of both nutrients and water have been attributed to Al (HORST et al., 2010).

In the present study, the reduction in root length was more pronounced in BRA than in JB/ UFSM (Figure 2a), which reinforces the previous observation that the JB/UFSM accession, based on tissue $\mathrm{Al}$ concentration, was more effective in $\mathrm{Al}$ avoidance than BRA. Recent research has found significant genetic variation in the size of the rhizosheaths in wheat when grown in Al toxic acid soils (DELHAIZE et al., 2012); in hydroponic experiments, the authors concluded that the higher Al tolerance in root hairs was a result of the larger rhizosheaths.

Although Al effects in shoot are considered long-term effects, for the most growth parameters evaluated, both $\boldsymbol{P}$. glomerata accessions showed a similar effective decrease in response to $\mathrm{Al}$ treatments. There was no significant interaction between $\boldsymbol{P}$. glomerata accessions and Al treatments for larger shoot length (Figure $2 \mathrm{~b}$ ); however in BRA accession, the larger shoot length showed a quadratic response, decreasing with Al supply (Figure 2b). On the other hand, the smaller shoot length (Figure 2c) decreased by Al supply in both accessions, showing a quadratic and linear response in BRA and JB/UFSM accessions, respectively. Moreover, the larger shoot length was greater in BRA accession than in JB/UFSM (Figure 2b), whereas the smaller shoot length showed in inverse response, which can be attributed to genetic differences. Although not as pronounced, there was a subtle reduction in the segments number of both $\boldsymbol{P}$. glomerata accessions with increasing Al supply (Figure 2d). Furthermore, the number of sprouts decreased linearly in BRA accession and showed a quadratic response in JB/UFSM, decreasing only at $200 \mathrm{mgL}^{-1} \mathrm{Al}$ when compared to the control (Figure 2e). The number of leaves showed a linear decrease with increasing Al supply in JB/UFSM accession, whereas it was quadratic in BRA accession (Figure $2 \mathrm{f}$ ). There are no reports in the literature about the effect of metaloid/metals on growth parameters of $\boldsymbol{P}$. glomerata, such as number of leaves and number and length of sprouts. On the other hand, the effect of benzylaminopurine and thidiazuron, two synthetic plant hormones, on in vitro organogenesis of $\boldsymbol{P}$. glomerata was reported to be genotype-dependent (FLORES et al., 2009). The most common responses of shoots to Al toxicity are cellular modifications in leaves, reduced stomatal opening, decreased photosynthetic activity, chlorosis and foliar necrosis (VITORELLO et al., 2005). In plants, the foliar symptoms to Al toxicity resemble those of phosphorous (P) deficiency (overall stunting, small, dark green leaves and late maturity, purpling of stems, leaves, and leaf veins, yellowing and death of leaf tips). In some cases, Al toxicity appears as an induced calcium $(\mathrm{Ca})$ deficiency (curling or rolling of young leaves and collapse of growing points or petioles) (FOY, 1984).

There was a significant interaction between $\boldsymbol{P}$. glomerata accessions and Al supply on the root, shoot and total dry weight (Figure 3a, $3 b, 3 c)$. However, for the ratio of root and shoot dry weight there was no significant interaction between accessions and Al supply (Figure 3d). Shoot and total dry weight of plants were reduced by $\mathrm{Al}$ treatments (Figure $3 \mathrm{a}$ and $3 \mathrm{c}$ ). On the other hand, root dry weight in BRA showed a cubic response, increasing at lower Al concentrations and decreasing at higher $\mathrm{Al}$ concentrations (Figure 3b). JB/UFSM accession showed decrease in root dry weight upon addition of $\mathrm{Al}$ supply, although at $200 \mathrm{mg} \mathrm{L}^{-1} \mathrm{Al}$ it was similar to the control (Figure 3b). P. glomerata accessions differed in dry matter production, where BRA showed higher shoot dry weight and JB/UFSM presented higher root dry weight. Higher shoot dry weight in BRA accession is due to its higher plant height than JB/UFSM. Other reports also showed decreases in plant dry weight under Al stress, such as for Eruca sativa (SANTOS et al., 2010) and for Oryza sativa (MENDONÇA et al., 2003).

Taking into account that $\boldsymbol{P}$. glomerata has shown some degree of heavy metal tolerance, such as for Cd (SKREBSKY et al., 2008), Hg (CALGAROTO et al., 2011), and for Pb (GUPTA et al., 2011), as well as for $\mathrm{Al}$ as shown in the present study, and considering that the ingestion of Al has a great potential risk to human health, the screening for genotypes of $\boldsymbol{P}$. glomerata that accumulate less Al and other metals mainly in the root tissues must be prioritized for purposes of cropping. 

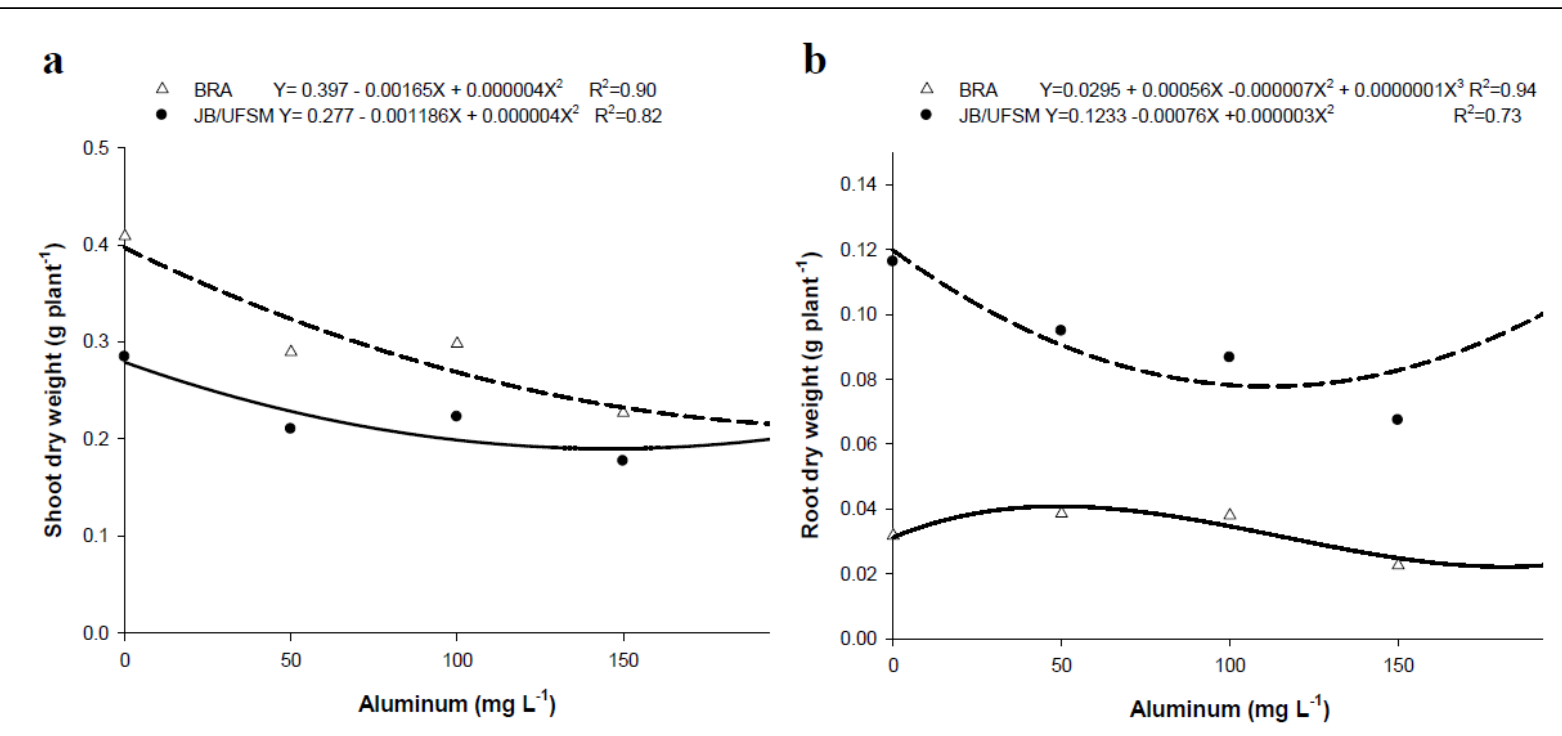

c
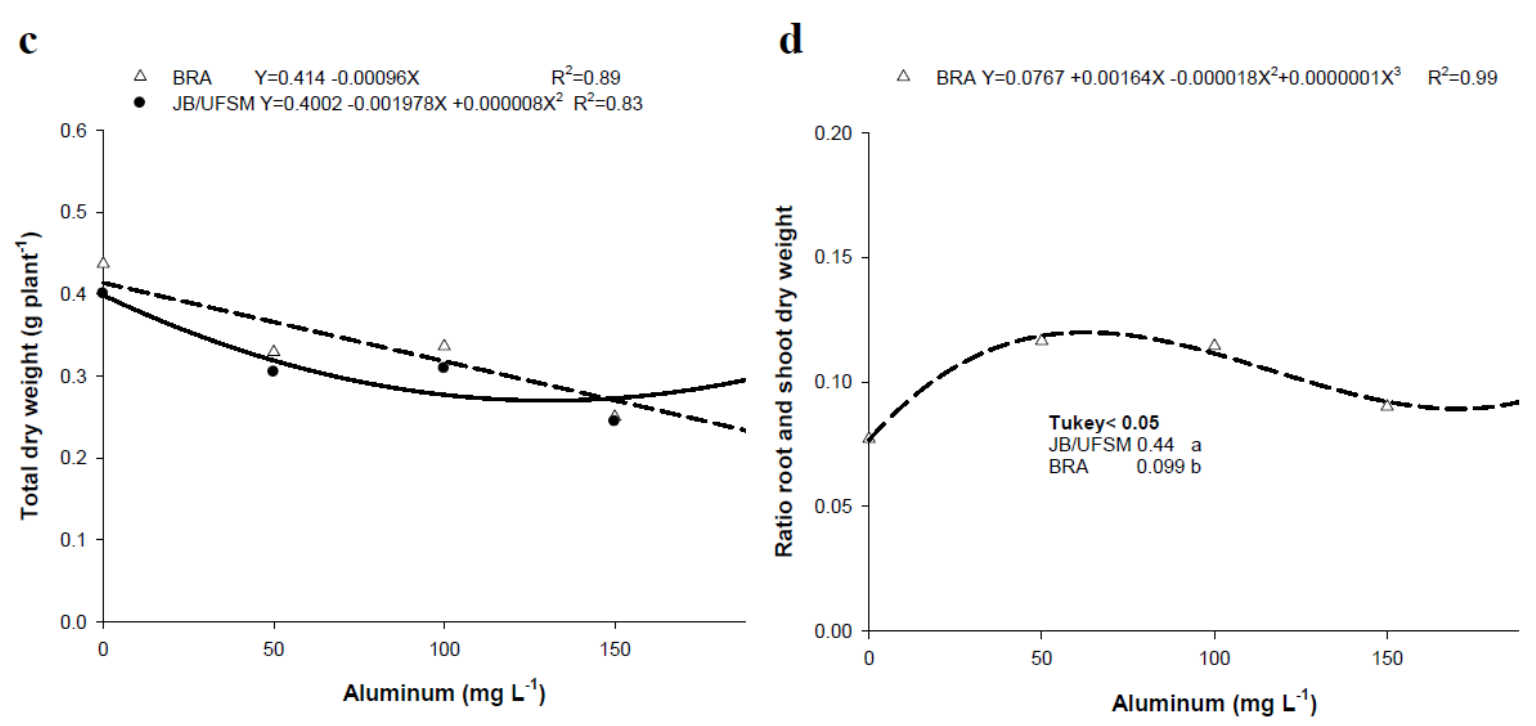

Figure 3 - Effect of increasing Al concentration on the shoot (a), root (b), and total (c) dry weight and ratio of root and shoot dry weight (d) of two accessions (BRA and JB) of Pfaffia glomerata. Tukey test was applied when regression was not significantly.

\section{CONCLUSION}

High Al levels were accumulated in roots of $\boldsymbol{P}$. glomerata, and the BRA accession had significantly higher $\mathrm{Al}$ concentrations than the JB/UFSM accession. As a consequence, in BRA accession the growth parameters were more negatively affected than in JB/UFSM. Based on these results it is suggested that the JB/UFSM accession seems to be more suitable for utilization in medicinal purposes than BRA when grown in soils with high Al levels.

\section{ACKNOWLEDGEMENTS}

The authors what to thank the Conselho Nacional de Desenvolvimento Científico e Tecnológico (CNPq), Coordenação e Aperfeiçoamento de Pessoal de Nível Superior (CAPES) and Fundação de Amparo à Pesquisa do Estado do Rio Grande do Sul (FAPERGS).

\section{REFERENCES}

AL-QAHTANI, K.M. Assessment of heavy metals accumulation in native plant species from soils contaminated in Riyadh City, Saudi Arabia. Life Science Journal, 
v.9, n.2, p.384-392, 2012. Available from: <http://www. lifesciencesite.com/1sj/>. Accessed: Oct. 10, 2013. doi: $10.3923 /$ rjet.2011.162.179

BRUNNER, I.; SPERISEN, C. Aluminum exclusion and aluminum tolerance in woody plants. Front Plant Science v.4, p.1-12, 2013. Available from: <http://www.ncbi.nlm.nih. gov/pmc/articles $>$. Accessed: Oct. 13, 2013. doi: 10.3389/ fpls.2013.00172.

CALGAROTO, N.S. et al. Zinc alleviates mercuryinduced oxidative stress in Pfaffia glomerata Spreng.) Pedersen. Biometals, v.24, p.959-971, 2011. Accessed Jan. 29, 2013 Available from: <http://www.ncbi.nlm. nih.gov/pubmed/21553242>. doi: 10.1007/s10534-0119457-y.

CASTILHOS, G. et al. Aluminum-stress response in oat genotypes with monogenic tolerance. Environmental and Experimental Botany, v.74, p.114-121, 2011. Available from: $\quad<$ http://www.sciencedirect.com/science/article/pii/ S0098847211001183>. Accessed: Jul. 03, 2013. doi: 10.1016/j. envexpbot.2011.05.007.

DELHAIZE, E. et al. Aluminium tolerance of root hairs underlies genotypic differences in rhizosheath size of wheat (Triticum aestivum) grown on acid soils. New Phytologist, v.195, p.609-619, 2012. Available from: <http://www.ncbi.nlm. nih.gov/pubmed/22642366>. Accessed: Sept. 10, 2013. doi: $10.1111 /$ j.1469-8137.2012.04183.x.

FLORES, R. et al. Benzilaminopurina (BAP) e thidiazuron na propagação in vitro de Pfaffia glomerata (Spreng.) Pedersen. Revista Brasileira de Plantas Medicinais, v.11, p.292-299, 2009. Available from: <http://www.scielo.br/pdf/rbpm/v11n3/10.pdf >. Accessed: Jul. 21, 2010.

FORTUNATO, R.P.; NICOLOSO, F.T. Toxidez de alumínio em plântulas de grápia (Apuleia leiocarpa Vog. Macbride) Ciência Rural, v.34, p.89-95, 2004. Available from: <http:// www.scielo.br/pdf/cr/v34n1/a14v34n1.pdf>. Accessed: Jun. $30,2006$.

FOY, C.D. Physiological effects of hydrogen, aluminium and manganese toxicities in acid soil. In: PEARSON, R.W.; ADAMS, F. (Eds.). Soil acidity and liming. 2.ed. Wisconsin: American Society of Agronomy, 1984. p.57-97.

GUPTA, D.K. et al. Lead induced responses of Pfaffia glomerata, an economically important Brazilian medicinal plant, under in vitro culture conditions. Bulletin of Environmental Contamination and Toxicology, v.86, p.272277, 2011. Available from: <http://www.ncbi.nlm.nih.gov/ pubmed/21336859>. Accessed: Mar. 09, 2013. doi: 10.1007/ s00128-011-0226-y.

HORST, W.J. et al. The role of the root apoplast in aluminum-induced inhibition of root elongation and in aluminum resistance of plants: a review. Annals of Botany, v.106, p.185-197, 2010. Available from: <http:// www.aob.oxfordjournals.org >. Accessed: Aug. 19, 2012. doi: $10.1093 / \mathrm{aob} / \mathrm{mcq} 053$.

KOCHIAN, L.V. et al. How do crop plants tolerate acid soils? - Mechanisms of aluminum tolerance and phosphorus efficiency. Annual Review Plant Biology, v.55, p.459-
493, 2004. Available from: <http://www.annualreviews. org/doi/pdf/10.1146/annurev.arplant.55.031903.141655> Accessed: Jun. 04, 2012 . doi: 10.1146/annurev. arplant.55.031903.141655.

KOPITTKE, P.M. et al. Toxicities of soluble Al, $\mathrm{Cu}$, and $\mathrm{La}$ include ruptures to rhizodermal and root cortical cells of cowpea. Plant and Soil, v.303, p.217227, 2008. Available from: <http://link.springer.com/ article/10.1007>. Accessed: Aug. 19, 2012. doi: 10.1007/ s11104-007-9500-5.

MENDONÇA, R.J. et al. Efeito do alumínio na absorção e na utilização de macronutrientes em duas cultivares de arroz. Pesquisa Agropecuária Brasileira, v.8, p.843-848, 2003. Available from: $<$ http://www.scielo.br/pdf/pab/v38n7/18206.pdf $>$. Accessed: Sept. 10, 2013.

MIYASAKA, S.C. et al. Aluminum. In: BARKER, A.V.; PILBEAM, D.J. (Eds.). Handbook of plant nutrition. Boca Raton, FL. Tayler and Francis Group, 2007. p.439-497.

MURASHIGE, T.; SKOOG, F. A revised medium for rapid growth and bioassays with tobacco tissue cultures. Physiologia Plantarum, v.15, p.473-497, 1962.

NICOLOSO, F.T. et al. Micropropagação do Ginseng Brasileiro [Pfaffia glomerata (Spreng.) Pedersen]. Revista Brasileira de Plantas Medicinais, v.3, p.11-18, 2001.

NISHIMOTO, N. et al. Ecdysteroids from Pfaffia iresinoides and reassignment of some ${ }^{13} \mathrm{CNMR}$ chemical shifts. Phytochemistry, v.26, p.2505-2507, 1987.

PEREIRA, L.B. et al. Effect of aluminum on $\delta$-aminolevulinic acid dehydratase (ALA-D) and the development of cucumber (Cucumis sativus). Environmental and Experimental Botany, v.57, p.106-115, 2006. Available from: <http://www.sciencedirect. com/science/S098720500717>. Accessed: Aug. 19, 2012. doi:10.1016/j.envexpbot.2005.05.004.

SANTOS, C.A.C. et al. Rúcula em cultivo hidropônico submetida a diferentes concentrações de alumínio. Bioscience Journal, v.26, n.6, p.905-912, 2010. Available from: <http://www.seer.ufu.br/ index.php/biosciencejournal/article/7231>. Accessed: Aug. 19, 2013

SINGH, D. et al. Developing aluminum-tolerant crop plants using biotechnological tools. Current Science, v.100, p.25, 2011. Available from: <http://www.currentscience.ac.in/cs/ Volumes/100/12/1807.pdf>. Accessed: Mar. 21, 2010.

SKREBSKY, E.C. et al. Effect of cadmium on growth, micronutrient concentration, and $\delta$-aminolevulinic acid dehydratase and acid phosphatase activities in plants of Pfaffia glomerata. Brazilian Journal of Plant Physiology, v.20, p.285-294, 2008. Available from: <http://www.scielo.br/ scielo.php>. Accessed: Jun, 14, 2011. doi.org/10.1590/S167704202008000400004

TABALDI, L.A. et al. Oxidative stress is an early symptom triggered by aluminum in Al-sensitive potato plantlets. Chemosphere, v.76, p.1402-1409, 2009. Available from: <http://www.ncbi.nlm.nih.gov/ pubmed/19570563>. Accessed: Jun, 14, 2011. doi: 10.1016/j.chemosphere.2009.06.011. 
TENNANT. D. A test of a modified line intersect method of estimating root length. Journal of Ecology, v.63, p.995-1001, 1975.

VITORELLO, V.A. et al. Recent advances in aluminum toxicity and resistance in higher plants. Brazilian Journal of Plant Physiology, v.17, p.129-143, 2005. Available from: http://www.scielo. br/scielo.php? pid $=$ S 1677-04202005000100011\&script $=$ sci arttext. Accessed: Feb. 04, 2012. doi: 10.1590/S167704202005000100011 .

WALTON, J.R. Cognitive deterioration and associated pathology induced by chronic low-level aluminum ingestion in a translational rat model provides an explanation of Alzheimer's disease, tests for susceptibility and avenues for treatment. International Journal of Alzheimer's Disease, v.2012, p.1-17, 2012. Available from: $<$ http://www.hindawi.com/journals/ijad/2012/914947/abs/>. Accessed: Abr. 13, 2013. doi: 10.1155/2012/914947.

YANG, J.L. et al. Genotypic difference among plant species in response to Al stress. Journal of Plant Nutrition, v.28, p.949961, 2005. Available from: <http://www.tandfonline.com/doi/ abs/10.1081>. Accessed: Jul, 28, 2008. doi: 10.1081/PLN200058884

YU, H.N. et al. The effect of aluminum treatments on root growth and cell ultrastructure of two soybean genotypes. Crop protection, v.30, p.323-328, 2011. Available from: <http://www. sciencedirect.com/science//S0264003467>. Accessed: Abr. 13, 2013. doi: 10.1016/j.cropro.2010.11.024. 